\title{
Effects of nitrogen source, concentration, and irradiance on growth rates of two diatoms endemic to northern San Francisco Bay
}

\author{
Gry Mine Berg ${ }^{1, *}$, Sara Driscoll ${ }^{1}$, Kendra Hayashi ${ }^{2}$, Raphael Kudela ${ }^{2}$ \\ ${ }^{1}$ Applied Marine Sciences, 911 Center Street, Santa Cruz, California 95060, USA \\ ${ }^{2}$ Ocean Sciences Department, 1156 High Street, University of California Santa Cruz, Santa Cruz, California 95064, USA
}

\begin{abstract}
Impacts on growth rates from exposure to ammonium $\left(\mathrm{NH}_{4}{ }^{+}\right)$and nitrate $\left(\mathrm{NO}_{3}{ }^{-}\right)$, at non-limiting concentrations, in combination with irradiances varying from 25 to $600 \mu \mathrm{mol}$ photons $\mathrm{m}^{-2} \mathrm{~s}^{-1}$ were investigated in the pelagic diatom Thalassiosira weisflogii and the benthic diatom Entomoneis paludosa recently isolated from Suisun Bay in northern San Francisco Bay. Growth rates were higher in $T$. weisflogii $\left(0.76 \pm 0.3 \mathrm{~d}^{-1}\right)$ compared with E. paludosa $\left(0.58 \pm 0.2 \mathrm{~d}^{-1}\right)$ across all irradiances and nitrogen $(\mathrm{N})$ treatments. Differences in growth rates with $\mathrm{N}$ source were regulated by irradiance in both diatoms and were greatest at the intermediate irradiance due to saturation of rates at $85 \mu \mathrm{mol}$ photons $\mathrm{m}^{-2} \mathrm{~s}^{-1}$ when growing on $\mathrm{NH}_{4}{ }^{+}$and at $200 \mu \mathrm{mol}$ photons $\mathrm{m}^{-2} \mathrm{~s}^{-1}$ when growing on $\mathrm{NO}_{3}{ }^{-}$. Notable physiological differences between these 2 diatoms included a larger range in the quantum yield of photosystem II $\left(F_{\mathrm{v}} / F_{\mathrm{m}}\right)$ and in chlorophyll a per cell as a function of irradiance in $T$. weissflogii compared with E. paludosa. In addition, a negative interaction of high $\mathrm{NH}_{4}{ }^{+}$concentration $\left(1000 \mu \mathrm{mol} \mathrm{l^{-1 }}\right)$ and irradiance $\left(\geq 200 \mu \mathrm{mol}\right.$ photons $\left.\mathrm{m}^{-2} \mathrm{~s}^{-1}\right)$ was observed on growth rates in E. paludosa that was not evident in T. weissflogii. Differences in physiological parameters of these diatoms are discussed in relation to their distributions and frequency of occurrence in Suisun Bay.
\end{abstract}

KEY WORDS: Ammonium - Irradiance - Diatoms - Entomoneis - Thalassiosira - Suisun Bay · San Francisco Bay

\section{INTRODUCTION}

Suisun Bay, situated in the northern part of San Francisco Bay, USA, has experienced numerous environmental changes in the last 2 to 3 decades, some of which have contributed to a general decline in phytoplankton biomass (Alpine \& Cloern 1992, Lehman 1996, 2000, Jassby 2008). These changes include increased grazing pressure following an invasion by the Asian clam Potamocorbula amurensis (Carlton et al. 1990, Alpine \& Cloern 1992), increases in nitrogen (N) inputs from wastewater discharge (Jassby 2008), exposure to a broad suite of herbicides (Orlando et

*Corresponding author: berg@amarine.com al. 2014), changes in water residence times, and increases in water temperature (Jassby 2008), to mention a few. These changes were added on top of a system that already experienced acute light limitation (Cole \& Cloern 1984, 1987, Jassby et al. 2002) resulting from relatively high levels of sediments carried with the Sacramento River and localized windwave sediment resuspension (Goodwin \& Denton 1991, Ruhl \& Schoellhamer 2004, Moskalski \& Torres 2012, Schoellhamer et al. 2012). In turn, the decrease in phytoplankton biomass has been hypothesized to be partially responsible for decreases in biomass of higher trophic levels, including zooplankton and

(C) The authors 2019. Open Access under Creative Commons by Attribution Licence. Use, distribution and reproduction are unrestricted. Authors and original publication must be credited. 
pelagic fish (Kimmerer 2002, Müller-Solger et al. 2002, Sommer et al. 2007, Kimmerer et al. 2017).

Of the bottom-up factors that could negatively impact phytoplankton growth, the two that have received the most attention are excessive ammonium $\left(\mathrm{NH}_{4}{ }^{+}\right.$) build-up from wastewater effluent (Dugdale et al. 2007, Parker et al. 2012, Esparza et al. 2014, Kraus et al. 2017) and light limitation due to high turbidity (Cole \& Cloern 1984, 1987, Alpine \& Cloern 1988, Jassby et al. 2002). These factors are linked in that light limitation, resulting in low levels of primary productivity and biomass, allows dissolved nutrients to accumulate in the water column. As a result, the median chlorophyll a concentration in Suisun Bay $\left(2.0 \mathrm{\mu g} \mathrm{l}^{-1}\right)$ is $\sim 12$-fold lower than what could be expected if the ambient nitrogen available in the water column was converted into phytoplankton biomass (Cloern \& Jassby 2012).

While the impacts of elevated $\mathrm{NH}_{4}{ }^{+}$concentrations and low light have been studied separately in Suisun Bay, they have not been studied simultaneously under controlled conditions. The interaction between light and nutrients is particularly pertinent to Suisun Bay as it is a mosaic of different light-nutrient environments varying from deep, dark channels to shallow, well-lit banks (Alpine \& Cloern 1988) superimposed by steep concentration gradients in inorganic nutrients (Dugdale et al. 2007, Jassby 2008). To investigate the impact of changes in light and nutrients simultaneously on phytoplankton growth in Suisun Bay, several species of phytoplankton were isolated into pure cultures (Berg et al. 2017). By using recent isolates from upper San Francisco Bay, we avoided issues related to extrapolation of results using strains from other geographic regions to our locale as well as issues related to genetic adaptations resulting from growth at unnaturally high $\mathrm{N}$ (in most cases, nitrate only) concentrations for many decades (Lakeman et al. 2009). In addition, by using pure cultures rather than field populations, we were able to ascribe physiology associated with growth on different $\mathrm{N}$ sources to a particular phytoplankton taxon.

Two of the isolated species, Thalassiosira weissflogii and Entomoneis paludosa, were endemic to Suisun Bay and belong to genera that dominate phytoplankton community composition depending on season and location (Lehman 1996, Cloern \& Dufford 2005, Glibert et al. 2014). These 2 species are ecologically distinct in that $T$. weissflogii is a centric diatom residing in the pelagic zone, whereas E. paludosa is a pennate diatom comprising part of the microphytobenthos that typically resides on the sediment surface (Ribeiro et al. 2003, Forster \& Martin-Jézéquel
2005). Both pelagic and microphytobenthic communities may be exposed to gradients in irradiance and nutrients, but these gradients may differ in steepness. For example, gradients in irradiance may be less steep at the sediment surface compared with what is experienced by a phytoplankter that is mixed from the bottom to the surface of the water column. Because of lower mean irradiances, benthic productivity may be less than pelagic water column productivity (Kromkamp et al. 1995, Cullen \& MacIntyre 1998, Underwood \& Kromkamp 1999). In contrast, gradients in nutrients may be steeper in the sediments where organic matter deposition and nutrient remineralization are more concentrated compared with the water column (Admiraal 1977b, Krom 1991). In a previous report, both T. weissflogii and E. paludosa isolated from Suisun Bay were found to tolerate ammonium concentrations in excess of $1000 \mathrm{mmol}^{-1}$ (Berg et al. 2017). Environmental parameters such as salinity and temperature are also important with respect to the distributions of both pelagic and benthic phytoplankton (Admiraal 1977a, MacIntyre et al. 1996, Underwood \& Provot 2000, Boyd et al. 2013).

In addition to gradients at the sediment-water interface, microphytobenthic communities are frequently exposed to wind-induced waves and tides that scour the surface of the sediments and suspend them into the water column (de Jonge \& van Beusekom 1995). In San Francisco Bay, currents, tides, river flow, and wind combine to provide a high level of turbulence and water column churn (Cloern 1991, 1996, Moskalski \& Torres 2012). Benthic diatoms in this system become suspended together with sediments into the water column and increasingly dominate pelagic phytoplankton community composition (Glibert et al. 2014, Kraus et al. 2017). Given recent increases in contribution of benthic diatoms to pelagic phytoplankton community composition in Suisun Bay, high tolerance of benthic diatoms to ammonium $\left(\mathrm{NH}_{4}{ }^{+}\right)$, and elevated concentrations of $\mathrm{NH}_{4}{ }^{+}$in this system, we wanted to investigate whether tolerance to varying combinations of light and nutrients could help characterize the ecological niches of T. weissflogii and E. paludosa.

To characterize the extent to which growth rates of these diatoms would be modulated by exposure to varying $\mathrm{NH}_{4}{ }^{+}$concentrations in combination with varying irradiances, the impacts to growth rates of 3 different nitrogen $(\mathrm{N})$ concentrations (under nonlimiting conditions), using nitrate $\left(\mathrm{NO}_{3}{ }^{-}\right)$or $\mathrm{NH}_{4}{ }^{+}$as the sole source of $\mathrm{N}$ for growth, under 4 different irradiances, were investigated in $T$. weissflogii and E. paludosa. When T. weissflogii and E. paludosa were 
isolated from Suisun Bay for the present study, both were key members of the pelagic phytoplankton community. We also wanted to investigate whether any of the 3 factors tested ( $\mathrm{N}$ source, $\mathrm{N}$ concentration, or irradiance) influenced growth rates to the extent that the factor could affect the outcome of competition between these 2 species.

\section{MATERIALS AND METHODS}

\subsection{Sampling}

Samples of phytoplankton were surveyed and collected along a cruise track that traversed Suisun Bay and its principal freshwater source, the Sacramento River, on 28 to 29 January 2014. During the survey, 33 discrete stations were sampled from the R/V 'Questuary' from the northernmost Stn 32 at the I-80 bridge in the Sacramento River to the southernmost Stn 1 in Suisun Bay. Samples for enumeration of phytoplankton abundance and isolation of phytoplankton into pure cultures were collected at $1 \mathrm{~m}$ depth from a smaller subset of stations (12 stations) along this survey track using a rosette sampler. Temperature and salinity data were obtained from a CTD attached to the rosette sampler. In addition, data on turbidity at each station was obtained using a YSI 6600v2 sonde.

\subsection{Experimental conditions}

Whole water was brought back to the laboratory where clonal, non-axenic cultures of the estuarine diatoms Thalassiosira weissflogii and Entomoneis paludosa were established by micropipette isolations of single cells from Suisun Bay according to Berg et al. (2017). Sterile techniques were used during all aspects of culturing. Stock cultures were maintained at $85 \mu \mathrm{mol}$ photons $\mathrm{m}^{-2} \mathrm{~s}^{-1}$ at $15.5^{\circ} \mathrm{C}$ and a salinity of 10 using $\mathrm{NO}_{3}{ }^{-}$as the $\mathrm{N}$ source. Before the start of an experiment, cultures were spun down, rinsed with $\mathrm{N}$ free medium, and re-suspended in triplicate into dilute batch cultures containing $200 \mathrm{ml}$ of medium with f/2 nutrient + silica solution lacking N (Goldman $\&$ McCarthy 1978). The nutrient solution was modified by the addition of $\mathrm{N}$ to give final concentrations of 20,100, and $1000 \mathrm{mmol} \mathrm{l}^{-1}$, either in the form of $\mathrm{NH}_{4}{ }^{+}$or $\mathrm{NO}_{3}{ }^{-}$. In the case of the cultures with $\mathrm{NH}_{4}{ }^{+}$ added, the fraction of total ammonia $\left(\mathrm{NH}_{4}{ }^{+}+\mathrm{NH}_{3}\right)$ that was composed of unionized $\mathrm{NH}_{3}$ at a salinity of 10 , temperature of $15.5^{\circ} \mathrm{C}$, and $\mathrm{pH}$ of 8.3 (i.e. $3-6 \%$;
Khoo et al. 1977) was calculated to range from 0.6 to $1.2 \mu \mathrm{mol} \mathrm{l}^{-1}$ in the $20 \mu \mathrm{mol} \mathrm{NH}_{4}{ }^{+} \mathrm{l}^{-1}$ cultures, 3 to

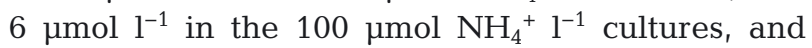
30 to $60 \mu \mathrm{mol} \mathrm{l^{-1 }}$ in the $1000 \mu \mathrm{mol} \mathrm{NH}_{4}{ }^{+} \mathrm{l}^{-1}$ cultures. Nitrogen concentrations were checked periodically throughout the growth phase of the cultures. Strains were cultured at 4 incident irradiances representing low $\left(25 \mu \mathrm{mol}\right.$ photons $\left.\mathrm{m}^{-2} \mathrm{~s}^{-1}\right)$, intermediate $(85 \mu \mathrm{mol}$ photons $\left.\mathrm{m}^{-2} \mathrm{~s}^{-1}\right)$, high $\left(200 \mu \mathrm{mol}\right.$ photons $\left.\mathrm{m}^{-2} \mathrm{~s}^{-1}\right)$, and inhibiting (600 $\mu \mathrm{mol}$ photons $\mathrm{m}^{-2} \mathrm{~s}^{-1}$ ) light. The cultures were mainatained on a $12 \mathrm{~h}$ light:12 $\mathrm{h}$ dark (L:D) cycle under cool-white fluorescent lights at a temperature of $15.5 \pm 1^{\circ} \mathrm{C}$ ). Each culture was sampled daily, at noon, for physiological evaluations as described below.

\subsection{Sample analyses}

The physiology of each species was evaluated through daily measurements of the quantum yield of photosystem II (PSII), cell abundance, and chlorophyll a (chl a) concentration. Nitrogen concentrations $\left(\mathrm{NH}_{4}{ }^{+}\right.$and $\left.\mathrm{NO}_{3}{ }^{-}\right)$were assayed periodically. The quantum yield of PSII $\left(F_{\mathrm{v}} / F_{\mathrm{m}}\right)$ was measured by pulseamplitude-modulated (PAM) fluorometry (HeinzWalz WATER-PAM). The PAM was blanked with $0.2 \mu \mathrm{m}$ filtered culture media. For assessment with PAM, aliquots were removed from the primary culture and dark-adapted for at least $10 \mathrm{~min}$. After dark adaptation, background chl a fluorescence $\left(F_{0}\right)$ and maximal chl a fluorescence following a saturating pulse $\left(F_{\mathrm{m}}\right)$ were measured to derive the variable $\left(F_{\mathrm{v}}\right)$ over maximum chl a fluorescence according to:

$$
\frac{F_{\mathrm{v}}}{F_{\mathrm{m}}}=\left(F_{\mathrm{m}}-F_{0}\right) / F_{\mathrm{m}}
$$

Samples for cell enumeration were preserved with acid Lugol's solution ( $20 \mu \mathrm{l}$ Lugol's per ml culture volume) and stored cool $\left(4^{\circ} \mathrm{C}\right)$ in the dark until enumeration with a Zeiss Axiovert 200 inverted microscope using a Parsons counting chamber. Geometric shapes of the cells were based on measurements of 10 organisms per taxon. Cell volumes were estimated by applying the geometric shapes that most closely matched the cell shape (Hillebrand et al. 1999). Abundances were estimated by random field counts totaling 400 unicells. Cell-specific growth rates $\left(\mathrm{d}^{-1}\right)$ were computed by fitting the exponential function:

$$
C=C_{0} \mathrm{e}^{\mu t}
$$

to the data from the exponential growth phase, where $C$ is the cell abundance, $C_{0}$ is the starting cell abun- 
dance, $\mu$ is the growth constant $\left(\mathrm{d}^{-1}\right)$, and $t$ is time (d). All calculations and statistical tests were carried out using R software (R Core Team 2016).

Samples for chl a determination were collected onto glass-fiber filters (Whatman GF/F) and processed immediately using the non-acidification method (Welschmeyer 1994). Samples for nutrient $\left(\mathrm{NO}_{3}{ }^{-}\right.$and $\left.\mathrm{NH}_{4}{ }^{+}\right)$analysis were filtered (Whatman $\mathrm{GF} / \mathrm{F}$ ) and stored frozen until processing. Ammonium was analyzed using the orthophthaldialdehyde (OPA) method, and relative fluorescence units were obtained via fluorometry (TD-700, Turner Designs) according to Holmes et al. (1999). Nitrate was analyzed using a Lachat QuikChem 8500 Flow Injection Analyst System and Omnion 3.0 software (Lachat Instruments, Hach).

\section{RESULTS}

At the time of sampling, phytoplankton belonging to the Thalassiosira genus dominated phytoplankton community biomass throughout Suisun Bay, whereas Entomoneis paludosa dominated phytoplankton community biomass at stations in the $\mathrm{X} 2$ region where the salinity changes from freshwater to brackish water (Fig. 1). For the current study, T. weissflogii was isolated from Stn 6, while E. paludosa was isolated from Stn 19. Salinities were 11.5 and 1.4 , and turbidities were 5 and 15 NTU, at Stns 6 and 19, respectively (Fig. $1 \mathrm{~A}, \mathrm{~B})$. The temperature was $11^{\circ} \mathrm{C}$ at both stations. These newly isolated diatom species were relatively large (Fig. 2). The dimensions for E. paludosa were approximately $50 \mu \mathrm{m}$ length by $20 \mu \mathrm{m}$ width,
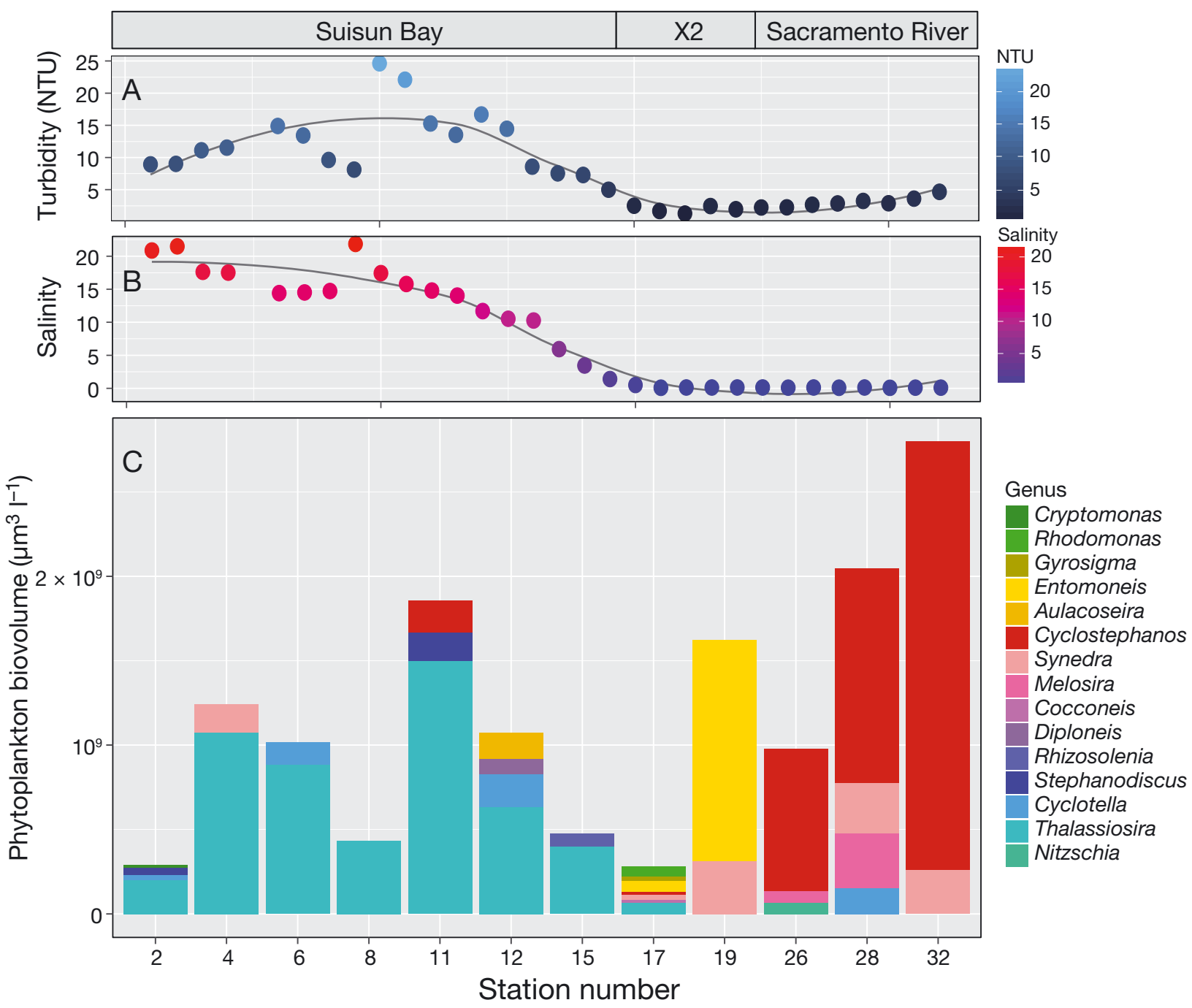

Fig. 1. (A) Turbidity, (B) salinity, and (C) phytoplankton community composition based on biovolume along the salinity gradient from the Sacramento River to Suisun Bay. Thalassiosira genus represented in teal, and Entomoneis genus represented in yellow. 


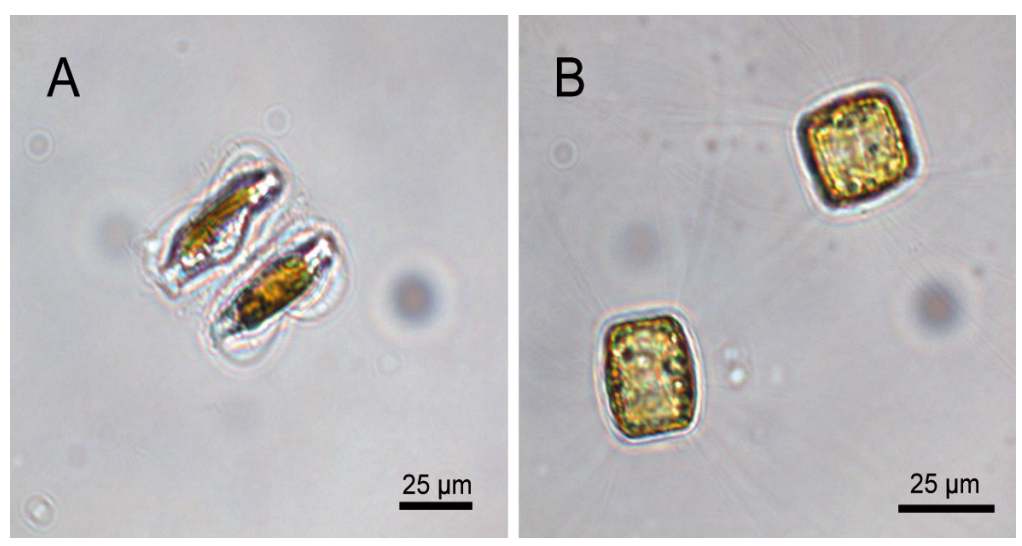

Fig. 2. Light microscopy image of a culture of (A) E. paludosa and (B) T. weissflogii. Scale bar $=25 \mu \mathrm{m}$

yielding a mean cell volume of $15580 \pm 2500 \mu^{3}$. The mean diameter of $T$. weissflogii was $32 \mu \mathrm{m}$, yielding a mean cell volume of $6447 \pm 804 \mu^{3}$ (Fig. 2).

$F_{\mathrm{v}} / F_{\mathrm{m}}$ was slightly greater in E. paludosa (ranging from 0.49 to 0.76 ) than $T$. weissflogii (ranging from 0.39 to 0.74 ) particularly at the intermediate irradiance (Fig. 3A-D). However the difference in $F_{\mathrm{v}} / F_{\mathrm{m}}$ as a function of species was not statistically significant $\left(F_{1,142}=3.4, \mathrm{p}=0.07\right)$. Nor was the difference in $F_{\mathrm{v}} / F_{\mathrm{m}}$ as a function of $\mathrm{N}$ source statistically different in either E. paludosa $\left(F_{1,70}=0.02, \mathrm{p}=0.89\right)$ or $T$. weissflogii $\left(F_{1,70}=1.2, \mathrm{p}=0.27\right)$. Similarly, there was no significant effect of $\mathrm{N}$ concentration on $F_{\mathrm{v}} / F_{\mathrm{m}}$ in either E. paludosa $\left(\mathrm{r}^{2}=2.11 \times 10^{-5}, F_{1,70}=0.0015, \mathrm{p}=\right.$ 0.97 ) or $T$. weissflogii $\left(\mathrm{r}^{2}=0.025, F_{1,70}=1.8, \mathrm{p}=0.18\right)$. In contrast to the aforementioned factors, $F_{\mathrm{v}} / F_{\mathrm{m}}$ decreased significantly with increasing irradiance in both E. paludosa $\left(\mathrm{r}^{2}=0.75\right.$, slope $=-3.20 \times 10^{-4}$, $\left.F_{1,70}=209, \mathrm{p}<2 \times 10^{-16}\right)$ and T. weissflogii $\left(\mathrm{r}^{2}=0.76\right.$, slope $=-3.43 \times 10^{-4}, F_{1,70}=222, \mathrm{p}<2 \times 10^{-16}$ ). In E. paludosa, the decrease in $F_{\mathrm{v}} / F_{\mathrm{m}}$ was greatest between 85 and $200 \mu \mathrm{mol}$ photons $\mathrm{m}^{-2} \mathrm{~s}^{-1}$ (Fig. 3A,B), whereas in $T$. weissflogii, it decreased with each step increase in irradiance (Fig. 3C,D).

Chl a quota (chl a cell-1) was significantly less for $E$. paludosa, ranging from 32 to $91 \mathrm{pg} \mathrm{cell}^{-1}$, compared with $T$. weissflogii $\left(\mathrm{F}_{1,142}=179, \mathrm{p}<2 \times 10^{-16}\right)$, where it ranged from 61 to $283 \mathrm{pg} \mathrm{cell}^{-1}$ (Fig. 3E-H). There was no significant effect of $\mathrm{N}$ source on cell quota in either species ( $E$. paludosa $F_{1,70}=0.8, \mathrm{p}=0.38 ; \mathrm{T}$. weissflogii $F_{1,70}=0.5, \mathrm{p}=0.48$ ). There was a slight effect of $\mathrm{N}$ concentration on cell quota in $E$. paludosa $\left(\mathrm{r}^{2}=0.06\right.$, slope $\left.=0.01, F_{1,70}=4.8, \mathrm{p}=0.03\right)$ but not in T. weissflogii $\left(F_{1,70}=0.5, \mathrm{p}=0.48\right)$. The effect of irradiance also differed with respect to the chl a quota in the 2 diatoms. There was no significant effect of irradiance on the chl a quota in E. paludosa $\left(F_{1,70}=0.08\right.$, $p=0.78$ ), which decreased between the low and intermediate irradiance followed by a slight increase above the intermediate irradiance (Fig. 3E,F). In contrast with E. paludosa, there was a significant negative effect of irradiance on the chl $a$ quota in $T$. weissflogii $\left(\mathrm{r}^{2}=0.45\right.$, slope $=$ $\left.-0.21, F_{1,70}=57, \mathrm{p}=1.2 \times 10^{-10}\right)$. In $T$. weissflogii, the chl a quota decreased with each step increase in irradiance between low and high irradiance when grown on $\mathrm{NH}_{4}{ }^{+}$(Fig. 3G) and between intermediate and high irradiance when grown on $\mathrm{NO}_{3}{ }^{-}$(Fig. 3H).

Growth rates differed significantly between the 2 diatoms tested here $\left(F_{1,142}=\right.$ $18, \mathrm{p}=3.7 \times 10^{-5}$ ), with rates being greater in $T$. weissflogii $\left(0.76 \pm 0.3 \mathrm{~d}^{-1}\right)$ compared with E. paludosa $\left(0.58 \pm 0.2 \mathrm{~d}^{-1}\right)$ across all treatments (Fig. 3I-L). Growth rates in both E. paludosa $\left(\mathrm{r}^{2}=0.17\right.$, slope $=$ $\left.0.0038, F_{1,70}=14, \mathrm{p}=0.00038\right)$ and $T$. weissflogii $\left(\mathrm{r}^{2}=\right.$ 0.41 , slope $=0.0008, F_{1,70}=48, \mathrm{p}=1.6 \times 10^{-9}$ ) were significantly impacted by irradiance. In both diatoms, the largest increase in growth rate occurred between the low and intermediate irradiances when grown on $\mathrm{NH}_{4}{ }^{+}$(Fig. 3I,K). When grown on $\mathrm{NO}_{3}{ }^{-}$, there was an additional increase between the intermediate and high irradiance (Fig. 3J,L).

In contrast with irradiance, there was no significant impact on growth rate in E. paludosa $\left(F_{1,70}=0.3, \mathrm{p}=\right.$ $0.6)$ or $T$. weissflogii $\left(F_{1,70}=3.5, \mathrm{p}=0.07\right)$ by either $\mathrm{N}$ source or $\mathrm{N}$ concentration $\left(F_{1,70}=4, \mathrm{p}=0.06\right.$ and $F_{1,70}=$ $0.02, \mathrm{p}=0.88$, respectively) across all irradiances (Fig. 3I-L). However, there was a negative interaction between growth on the highest $\mathrm{NH}_{4}{ }^{+}$concentration and the 2 highest irradiances in E. paludosa (Fig. 3I). As a result, growth rates in E. paludosa decreased $40 \%$ from the intermediate to high irradiance when grown at $1000 \mu \mathrm{mol} \mathrm{NH}_{4}{ }^{+} \mathrm{l}^{-1}$ (Fig. 3I). No such decrease was observed when grown on $\mathrm{NO}_{3}{ }^{-}$(Fig. 3J).

There was an effect of $\mathrm{N}$ source on growth rate at the intermediate irradiance in T. weissflogii (Fig. 3K-L, $\left.F_{1,16}=187, \mathrm{p}=3.05 \times 10^{-10}\right)$. At this irradiance, growth on $\mathrm{NH}_{4}{ }^{+}$was $69 \%$ faster than growth on $\mathrm{NO}_{3}{ }^{-}$ (Fig. 4). Although not statistically significant, growth rates were also faster (28\%) on $\mathrm{NH}_{4}{ }^{+}$than on $\mathrm{NO}_{3}{ }^{-}$in E. paludosa at the intermediate irradiance (Fig. 4). This difference in growth rates with $\mathrm{N}$ source at the intermediate irradiance can be attributed to the difference in irradiance at which maximum growth rates were reached when growing on $\mathrm{NH}_{4}{ }^{+}$vs $\mathrm{NO}_{3}{ }^{-}$. In both species, near-maximum growth rates were reached at the intermediate irradiance when grow- 


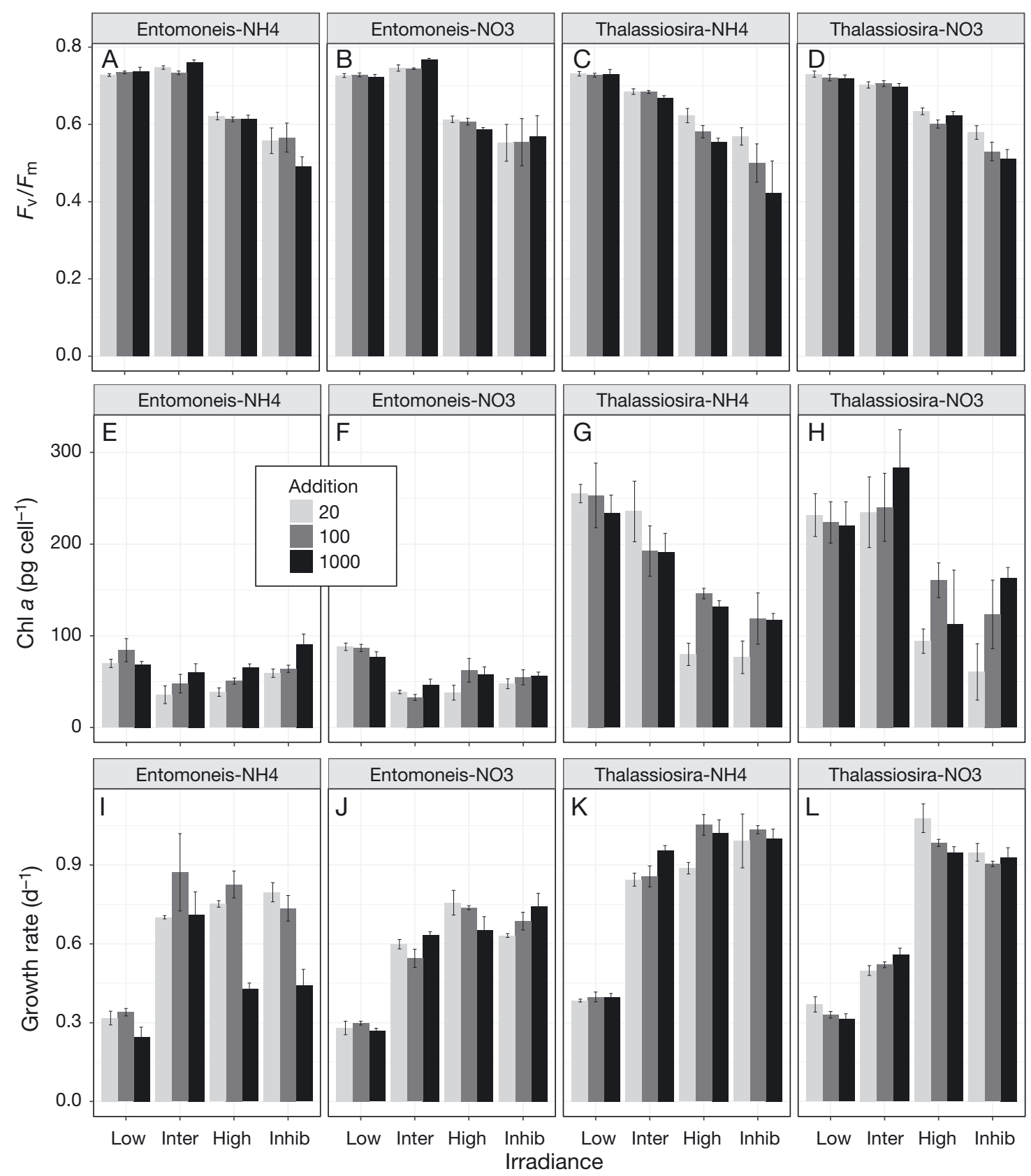

Fig. 3. Species-specific differences with $\mathrm{N}$ source and $\mathrm{N}$ addition in mid-exponential growth phase of $(\mathrm{A}-\mathrm{D}) F_{\mathrm{v}} / F_{\mathrm{m}}(\mathrm{E}-\mathrm{H}) \mathrm{chl} a$ (pg cell $\left.{ }^{-1}\right)$, and (I-L) growth rates $\left(\mathrm{d}^{-1}\right)$ as a function of irradiance for E. paludosa and T. weissflogii. Mean of triplicate cultures \pm standard error of the mean. Inter: intermediate; Inhib: inhibitory

ing on $\mathrm{NH}_{4}{ }^{+}$, while the maximum was not reached until the high irradiance when growing on $\mathrm{NO}_{3}{ }^{-}$ (Fig. 3J,L). As a result, the difference in growth rates between the $2 \mathrm{~N}$ sources was greatest at the intermediate irradiance. At the highest irradiances, growth rates on $\mathrm{NO}_{3}{ }^{-}$had caught up to rates on $\mathrm{NH}_{4}{ }^{+}$, and there was no substantial difference. At the lowest irradiance, growth rates were similarly low on both $\mathrm{N}$ sources in both species (Fig. 4).

\section{DISCUSSION}

In recent years, blooms of benthic diatoms have become more common in Suisun Bay in the northern portion of San Francisco Bay. In particular, occasional blooms of the benthic chain-forming diatom Entomoneis paludosa have been observed throughout Suisun Bay (e.g. Glibert et al. 2014). Because E. paludosa is a benthic species and therefore acclimated to 


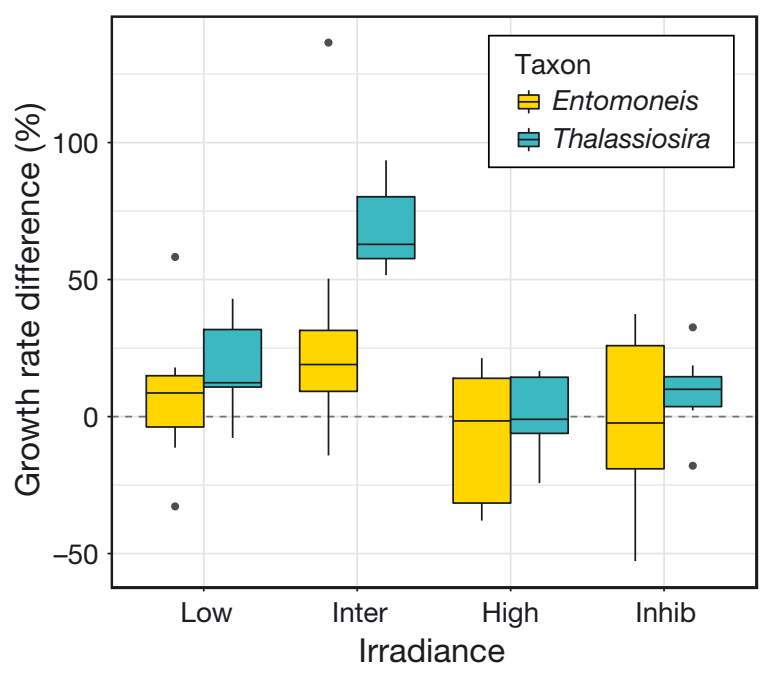

Fig. 4. Box plots of growth-rate differences with respect to $\mathrm{N}$ source as a percentage $\left(\left[\mu_{\mathrm{NH} 4} / \mu_{\mathrm{NO} 3}-1\right] \times 100\right)$ as a function of irradiance in E. paludosa and T. weissflogii. Dotted line represents no growth rate difference with $\mathrm{N}$ source. Line within box: median; box: interquartile range (IQR); whiskers: max./ min. values $\leq 1.5 \times$ IQR above/below box; circles: outliers

high $\mathrm{NH}_{4}{ }^{+}$concentrations fluxing out of the sediments (i.e. Admiraal 1977b, Jauffrais et al. 2016), and water column $\mathrm{NH}_{4}{ }^{+}$concentrations in Suisun Bay are relatively high (Jassby 2008), it is possible that pelagic blooms of this species are related to shifts in $\mathrm{N}$ concentration and species. It has been hypothesized that growth of pelagic diatoms is inhibited by $\mathrm{NH}_{4}{ }^{+}$at concentrations above $4 \mu \mathrm{mol} \mathrm{l}{ }^{-1}$ (Dugdale et al. 2007) although this has not been demonstrated on a physiological level (Collos \& Harrison 2014, Berg et al. 2017). We wanted to investigate how growth rates of the pelagic diatom Thalassiosira weissflogii, potentially more sensitive to $\mathrm{NH}_{4}{ }^{+}$and less sensitive to irradiance, and the benthic diatom E. paludosa, potentially less sensitive to $\mathrm{NH}_{4}{ }^{+}$and more sensitive to irradiance, would compare under varying conditions of irradiance and $\mathrm{N}$ sources and concentration at non-limiting levels of nutrients. We specifically tested non-limiting levels as earlier analyses had hypothesized that changes in $\mathrm{N}$ speciation at nonlimiting levels could affect phytoplankton growth rates and competitive interactions (Dugdale et al. 2007, Glibert et al. 2011). In contrast with earlier reports, no significant impact of $\mathrm{N}$ source on growth rates were demonstrated in the 2 diatom species tested here. Of the 3 environmental variables tested, irradiance had the largest and most significant influence on growth rates.

At the temperatures used in the current experiments $\left(15.5^{\circ} \mathrm{C}\right), T$. weissflogii outgrew E. paludosa across all treatments with an average growth rate difference of $0.18 \mathrm{~d}^{-1}$. This growth rate difference was greater at high light $\left(0.3 \mathrm{~d}^{-1}\right)$ compared with low light $\left(0.07 \mathrm{~d}^{-1}\right)$. We noted physiological differences between these 2 diatoms that could underpin the pattern of a larger growth rate difference at high light compared with low light. One was a smaller range in $F_{\mathrm{v}} / F_{\mathrm{m}}$ in E. paludosa compared with $T$. weissflogii, 0.27 vs. 0.35 , respectively. Another was less plasticity in chl a quota, varying 5-fold in E. paludosa and 11fold in T. weissflogii.

Being able to vary photosynthetic efficiency (shortterm acclimation response to excess irradiance) and chl a quota (longer-term acclimation response to excess irradiance) can enable a species to acclimate more readily in response to change and thereby avoid damage to the cell under high light. Effective dissipation of excess energy at the point where light energy is harvested, as heat or fluorescence, called non-photochemical quenching, can prevent the buildup electrons that combine with oxygen to form oxygen radicals that damage the D1 protein of PSII (Vass et al. 1992, Aro et al. 1993, Clarke et al. 1993, Wu et al. 2012). This damage results in inhibition of photosynthesis (photoinhibition) which may or may not be reversible depending on how efficient the cell's repair mechanisms are (Vass et al. 1992, Clarke et al. 1993, Nixon et al. 2010, Campbell \& Tyystjärvi 2012, $\mathrm{Wu}$ et al. 2012). Temporary diversion of excess energy reduces the photosynthetic efficiency of the cell but prevents long-term damage and mortality of the cells. Cells that do not have the ability to dissipate excess energy do not experience short-term decreases in photosynthetic efficiency but may not be able to adapt and as a consequence may not survive (Cullen \& MacIntyre 1998). It is possible that the ability of $T$. weissflogii to decrease its photosynthetic efficiency and its chl a quota to a greater degree than E. paludosa enables it to maintain a better level of photoprotection and to attain a higher growth rate at high irradiances.

In addition to having less plasticity in photophysiological parameters, there was a negative interaction of high irradiance and high $\mathrm{NH}_{4}{ }^{+}$concentration in $E$. paludosa, resulting in a $40 \%$ decrease in the growth rate, which was not evident in $T$. weissflogii. Such an interaction has been observed previously for E. paludosa (Admiraal 1977b), and it can be explained physiologically by direct damage to PSII from competitive binding of $\mathrm{NH}_{3}$ with the oxygen evolution complex (Kallqvist \& Svenson 2003, Drath et al. 2008, Collos \& Harrison 2014). In other words, addition of high concentrations of $\mathrm{NH}_{4}{ }^{+}$, a fraction of which will be com- 
posed of $\mathrm{NH}_{3}$ depending on temperature and $\mathrm{pH}$ (e.g. Khoo et al. 1977), will allow $\mathrm{NH}_{3}$ to diffuse freely into the cell, resulting in photodamage. The impact of this damage will depend on the photorepair mechanisms present in the cell (Drath et al. 2008). A negative impact on growth of high $\mathrm{NH}_{4}{ }^{+}$at high irradiances suggests that E. paludosa has an inferior photodamage repair mechanism compared with $T$. weissflogii. At the lower irradiances (25 to $85 \mu \mathrm{mol}$ photons $\mathrm{m}^{-2} \mathrm{~s}^{-1}$ ), growth in E. paludosa was not inhibited by the highest $\mathrm{NH}_{4}{ }^{+}$concentration tested here.

The combination of the high $\mathrm{NH}_{4}{ }^{+}$concentration with constant high irradiance used here would not be expected to occur in Suisun Bay where water column $\mathrm{NH}_{4}{ }^{+}$concentrations typically range from 2 to $11 \mu \mathrm{mol} \mathrm{l}{ }^{-1}$, fluxes of $\mathrm{NH}_{4}{ }^{+}$out of the sediments to the water column are below $100 \mu \mathrm{mol} \mathrm{NH}_{4}{ }^{+} \mathrm{m}^{-2} \mathrm{~h}^{-1}$ (Cornwell et al. 2014), and depth-averaged integrated irradiances are typically below $100 \mu \mathrm{mol}$ photons $\mathrm{m}^{-2} \mathrm{~s}^{-1}$ (Table 1). The intermediate irradiance used in the current experiments would probably be more applicable to depth-averaged irradiance conditions encountered in Suisun Bay (Table 1). Interestingly, the difference in growth rates between $\mathrm{NH}_{4}{ }^{+}$ and $\mathrm{NO}_{3}{ }^{-}$was the greatest in both species at the intermediate irradiance.

A large growth rate difference between $\mathrm{NH}_{4}{ }^{+}$and $\mathrm{NO}_{3}{ }^{-}$at intermediate irradiances, but not at low or high irradiances, has been observed in several other phytoplankton species (Paasche 1971, Thompson et

Table 1. Typical water column depth, $\mathrm{NH}_{4}{ }^{+}$concentrations, and irradiances (depth-averaged integrated irradiance) for select stations along the cruise track in Suisun Bay during summer and winter. Corresponding USGS long-term monitoring station designations in parentheses

\begin{tabular}{|lccc|}
\hline Station & $\begin{array}{c}\text { Depth } \\
(\mathrm{m})\end{array}$ & $\begin{array}{c}\mathrm{NH}_{4}^{+} \\
\left(\mu \mathrm{mol} \mathrm{l} \mathrm{l}^{-1}\right)\end{array}$ & $\begin{array}{c}\text { Irradiance } \\
(\mu \mathrm{mol} \text { photons } \\
\left.\mathrm{m}^{-2} \mathrm{~s}^{-1}\right)\end{array}$ \\
\hline Summer & & & \\
17 (USGS3) & 11.4 & 2.4 & 20.7 \\
12 (Grizzly Bay) & 6.4 & 4.5 & 62.0 \\
8 (Middle Suisun) & 5.9 & 4.7 & 62.7 \\
(USGS5) & 11 & 3.8 & 46.1 \\
4 (USGS6) & 12.5 & 5.9 & 41.3 \\
2 (USGS7) & 18 & 10.9 & 31.4 \\
Winter & & & \\
17 (USGS3) & 11.4 & 13.2 & 30.4 \\
12 (Grizzly Bay) & 6.4 & 10.2 & 78.6 \\
8 (Middle Suisun) & 5.9 & 10.2 & 15.4 \\
6 (USGS5) & 11 & 10.4 & 17.7 \\
4 (USGS6) & 12.5 & 10.9 & 26.1 \\
2 (USGS7) & 18 & 10.9 & 61.5 \\
\hline
\end{tabular}

al. 1989; Wood \& Flynn 1995, Tong et al. 2016). This difference can be explained by the maximum growth rate being reached at a lower irradiance when growing on $\mathrm{NH}_{4}{ }^{+}$than when growing on $\mathrm{NO}_{3}{ }^{-}$(i.e. Wood \& Flynn 1995), resulting from the requirement of additional energy (i.e. $25-40 \%$ ) and enzymatic steps associated with the reduction of $\mathrm{NO}_{3}{ }^{-}$(Thompson et al. 1989, Turpin 1991, Raven et al. 1992, Levasseur et al. 1993, Herrero et al. 2001, Brown et al. 2009). The difference in growth rates with $\mathrm{N}$ source may not be easy to detect unless a range of irradiances are tested as the difference disappears at higher (and lower) irradiances. Many studies have demonstrated no difference in growth regardless of $\mathrm{N}$ source, and some have greater growth rates on $\mathrm{NO}_{3}{ }^{-}$compared with $\mathrm{NH}_{4}{ }^{+}$(Thompson et al. 1989, Levasseur et al. 1993, Clark \& Flynn 2000, Herndon \& Cochlan 2007, Strom \& Bright 2009, Thessen et al. 2009, Berg et al. 2017). Whether a lack of growth rate difference with $\mathrm{N}$ source is due to testing at irradiances that are too high, and/or because the extra energy cost to the cell when using $\mathrm{NO}_{3}{ }^{-}$is compensated for by changes in metabolic parameters, is not clear. Previous studies have demonstrated variations in chl a quota, N quota, cellular C: $\mathrm{N}$ ratio, and photosynthetic efficiency with growth on $\mathrm{NO}_{3}{ }^{-}$versus $\mathrm{NH}_{4}{ }^{+}$(Levasseur et al. 1993, Wood \& Flynn 1995, Flynn 2001).

While there was a difference in growth rates with $\mathrm{N}$ source at the intermediate irradiance in the current experiment, averaged across all the irradiances, this difference was no longer significant in either diatom. Because phytoplankton in Suisun Bay are mixed from the top to the bottom of the water column (i.e. mixed layer depth is the same as the total water column depth; Cloern 1991) and therefore experience a range of irradiances in each mixing cycle, $\mathrm{N}$ source effects should be averaged across a range of irradiances. Another important note with respect to the use of different $\mathrm{N}$ sources is that, as demonstrated here and in other studies (Paasche 1971, Thompson et al. 1989, Wood \& Flynn 1995, Tong et al. 2016), irradiance is the principal driver. At any given irradiance, phytoplankton are likely to use the same $\mathrm{N}$ source or $\mathrm{N}$ mix. Consequently, all phytoplankton are more likely to use $\mathrm{NH}_{4}{ }^{+}$under the low-intermediate irradiances and non-limiting $\mathrm{NH}_{4}{ }^{+}$conditions that prevail in Suisun Bay, and competition among species will be driven by intrinsic growth rate differences rather than use of different $\mathrm{N}$ sources.

The reason that E. paludosa is able to bloom in parts of Suisun Bay, despite growing at a slower rate than species of the Thalassiosira genus, may not be linked to either irradiance or $\mathrm{NH}_{4}{ }^{+}$concen- 
trations. As illustrated in Fig. 1 the distribution of these 2 genera, when they co-occur, is at opposing ends of the salinity spectrum in Suisun Bay. Diatoms of the Thalassiosira genus tend to dominate at salinities $>1.5$, whereas E. paludosa dominates at salinities around 1.5 and less. A number of studies have indicated that salinity is an important factor with respect to distributions of phytoplankton and microphytobenthos and competitive interactions (McIntire 1978, Admiraal et al. 1984, Underwood et al. 1998, Underwood \& Provot 2000). Temperature is another potentially important factor in regulating growth rates and competitive interactions (Eppley 1972, Admiraal 1977a, Anderson 2000, Butterwick et al. 2005, Boyd et al. 2013). Studies to date suggest that the temperature optimum for growth of the Thalassiosira genus, between 15 and $20^{\circ} \mathrm{C}$ (Boyd et al. 2013), is lower than the temperature optimum of $E$. paludosa, which is $25^{\circ} \mathrm{C}$ (Admiraal 1977a). Because water temperatures have been increasing by up to $0.21^{\circ} \mathrm{C}$ per year in upper Suisun Bay and in the Delta (Jassby 2008), it may be that the warming of the water has provided an opportunity for E. paludosa to out-grow pelagic diatom species such as Thalassiosira spp. within a specific salinity range.

In summary, typical $\mathrm{NH}_{4}{ }^{+}$concentrations in Suisun Bay do not inhibit growth of either $T$. weissflogii or $E$. paludosa. At irradiances and mixing regimes characteristic of Suisun Bay, the pelagic diatom $T$. weissflogii would likely be at a competitive advantage given its higher growth rates and photophysiological adaptations suitable for exploiting variable irradiance. Our findings are consistent with global findings that pelagic diatoms are adapted for growth in low-light environments with a high degree of turbulence (Margalef 1978, Kudela 2010, Edwards et al. 2015, Richardson et al. 2016) and that pelagic diatoms typically have higher rates of primary productivity than benthic diatoms (Kromkamp et al. 1995, Underwood \& Kromkamp 1999). Episodic blooms of pelagic versus microphytobenthic species in Suisun Bay could be controlled by variations in water column stability, temperature, and salinity. Increased residence time, and thereby increased stratification and temperatures, could accelerate growth of E. paludosa at the sediment surface, allowing it to build up a large seed community. With an episodic increase in turbulence, this community could become suspended into the water column and outcompete centric pelagic diatoms from the Thalassiosira genus, as observed during the spring bloom of E. paludosa in 2014 at the height of drought conditions (Glibert et al. 2014).
Acknowledgements. Special thanks to Dane Hardin for help with statistical analyses. This research was funded through the Interagency Ecological Program by the Sacramento Regional County Sanitation District award 90000094 to R.K. and award 80000089 to G.M.B. Further support was provided through the California Water Resources Control Board Award 22-1509-5082 to R.K. and G.M.B., USDI Bureau of Reclamation award R14AP00053 to R.K., and the Central Contra Costa Sanitary District award 40969 to R.K. and award 42218 to G.M.B.

\section{LITERATURE CITED}

Admiraal W (1977a) Influence of light and temperature on the growth rate of estuarine benthic diatoms in culture. Mar Biol 39:1-9

Admiraal W (1977b) Tolerance of estuarine benthic diatoms to high concentrations of ammonia, nitrite ion, nitrate ion and orthophosphate. Mar Biol 43:307-315

Admiraal W, Peletier H, Brouwer T (1984) The seasonal succession patterns of diatom species on an intertidal mudflat: an experimental analysis. Oikos 42:30-40

Alpine AE, Cloern JE (1988) Phytoplankton growth rates in a light-limited environment, San Francisco Bay. Mar Ecol Prog Ser 44:167-173

Alpine AE, Cloern JE (1992) Trophic interactions and direct physical effects control phytoplankton biomass and production in an estuary. Limnol Oceanogr 37:946-955

Anderson NJ (2000) Miniview: diatoms, temperature and climatic change. Eur J Phycol 35:307-314

Aro EM, Virgin I, Andersson B (1993) Photoinhibition of photosystem II: inactivation, protein damage and turnover. Biochim Biophys Acta 1143:113-134

* Berg GM, Driscoll S, Hayashi K, Ross M, Kudela R (2017) Variation in growth rate, carbon assimilation, and photosynthetic efficiency in response to nitrogen source and concentration in phytoplankton isolated from upper San Francisco Bay. J Phycol 53:664-679

* Boyd PW, Rynearson TA, Armstrong EA, Fu F and others (2013) Marine phytoplankton temperature versus growth responses from polar to tropical waters - outcome of a scientific community-wide study. PLOS ONE 8:e63091

Brown KL, Twing KI, Robertson DL (2009) Unraveling the regulation of nitrogen assimilation in the marine diatom Thalassiosira pseudonana (Bacillariophyceae): diurnal variations in transcript levels for five genes involved in nitrogen assimilation. J Phycol 45:413-426

* Butterwick C, Heaney SI, Talling JF (2005) Diversity in the influence of temperature on the growth rates of freshwater algae, and its ecological relevance. Freshw Biol 50: 291-300

* Campbell DA, Tyystjärvi E (2012) Parameterization of photosystem II photoinactivation and repair. Biochim Biophys Acta 1817:258-265

Carlton JT, Thompson JK, Schemel LE, Nichols FH (1990) Remarkable invasion of San Francisco Bay (California, USA), by the Asian clam Potamocorbula amurensis. I. Introduction and dispersal. Mar Ecol Prog Ser 66:81-94

Clark DR, Flynn KJ (2000) The relationship between the dissolved inorganic carbon concentration and growth rate in marine phytoplankton. Proc Biol Sci 267:953-959

Clarke AK, Soitamo A, Gustafsson P, Oquist G (1993) Rapid interchange between two distinct forms of cyanobacterial photosystem II reaction-center protein D1 in response 
to photoinhibition. Proc Natl Acad Sci USA 90:9973-9977

Cloern JE (1991) Tidal stirring and phytoplankton bloom dynamics in an estuary. J Mar Res 49:203-221

Cloern JE (1996) Phytoplankton bloom dynamics in coastal ecosystems: a review with some general lessons from sustained investigation of San Francisco Bay, California. Rev Geophys 34:127-168

* Cloern JE, Dufford R (2005) Phytoplankton community ecology: principles applied in San Francisco Bay. Mar Ecol Prog Ser 285:11-28

Cloern JE, Jassby AD (2012) Drivers of change in estuarinecoastal ecosystem: discoveries from four decades of study in San Francisco Bay. Rev Geophys 50:RG4001

Cole BE, Cloern JE (1984) Significance of biomass and light availability to phytoplankton productivity in San Francisco Bay. Mar Ecol Prog Ser 17:15-24

Cole BE, Cloern JE (1987) An empirical model for estimating phytoplankton productivity in estuaries. Mar Ecol Prog Ser 36:299-305

Collos Y, Harrison PJ (2014) Acclimation and toxicity of high ammonium concentrations to unicellular algae. Mar Pollut Bull 80:8-23

Cornwell JC, Glibert PM, Owens MS (2014) Nutrient fluxes from sediments in the San Francisco Bay Delta. Estuaries Coasts 37:1120-1133

Cullen JJ, MacIntyre JG (1998) Behavior, physiology and the niche of depth-regulating phytoplankton. In: Anderson DM, Cembella AD, Hallegraeff GM (eds) Physiological ecology of harmful algal blooms. Springer-Verlag, Berlin, p 1-21

de Jonge VN, van Beusekom JEE (1995) Wind- and tideinduced resuspension of sediment and microphytobenthos from tidal flats in the Ems estuary. Limnol Oceanogr 40:766-778

* Drath M, Kloft N, Batschauer A, Marin K, Novak J, Forchammer K (2008) Ammonia triggers photodamage of photosystem II in the cyanobacterium Synechocystis sp. strain PCC 6803. Plant Physiol 147:206-215

Dugdale RC, Wilkerson FP, Hogue VE, Marchi A (2007) The role of ammonium and nitrate in spring bloom development in San Francisco Bay. Estuar Coast Shelf Sci 73: $17-29$

Edwards KF, Thomas MK, Klausmeier CA, Litchman E (2015) Light and growth in marine phytoplankton: allometric, taxonomic, and environmental variation. Limnol Oceanogr 60:540-552

Eppley RW (1972) Temperature and phytoplankton growth in the sea. Fish Bull 70:1063-1085

Esparza ML, Farrell AE, Craig DJ, Swanson C, Dhaliwal BS, Berg GM (2014) Impact of atypical ammonium concentrations on phytoplankton abundance and composition in fresh versus estuarine waters. Aquat Biol 21:191-204

Flynn KJ (2001) A mechanistic model for describing dynamic multi-nutrient, light, temperature interactions in phytoplankton. J Plankton Res 23:977-997

Forster R, Martin-Jézéquel V (2005) Photophysiological variability of microphytobenthic diatoms after growth in different types of culture conditions. Phycologia 44: 393-402

* Glibert PM, Fullerton D, Burkholder JM, Cornwell JC, Kana TM (2011) Ecological stoichiometry, biogeochemical cycling, invasive species, and aquatic food webs: San Francisco Estuary and comparative systems. Rev Fish Sci 19:358-417

Glibert PM, Dugdale RC, Wilkerson F, Parker AE and others
(2014) Major-but rare-spring blooms in 2014 in San Francisco Bay Delta, California, a result of the long-term drought, increased residence time, and altered nutrient loads and forms. J Exp Mar Biol Ecol 460:8-18

Goldman JC, McCarthy JJ (1978) Steady state growth and ammonium uptake of a fast-growing marine diatom. Limnol Oceanogr 23:695-703

Goodwin P, Denton RA (1991) Seasonal influences on the sediment transport characteristics of the Sacramento River. Proc Inst Civ Eng 91:163-172

*Herndon J, Cochlan WP (2007) Nitrogen utilization by the raphidophyte Heterosigma akashiwo: growth and uptake kinetics in laboratory cultures. Harmful Algae 6: 260-270

* Herrero A, Muro-Pastor AM, Flores E (2001) Nitrogen control in cyanobacteria. J Bacteriol 183:411-425

Hillebrand H, Dürselen CD, Kivschtel D, Pollingsher M, Zohary $\mathrm{T}$ (1999) Biovolume calculation for pelagic and benthic microalgae. J Physiol 35:403-424

Holmes RM, Aminot A, Kerouel R, Hooker BA, Peterson BJ (1999) A simple and precise method for measuring ammonium in marine and freshwater ecosystems. Can J Fish Aquat Sci 56:1801-1808

Jassby AD (2008) Phytoplankton in the upper San Francisco Estuary: recent biomass trends, their causes and their trophic significance. San Fran Estuar Watershed Sci 6: $1-24$

Jassby AD, Cloern JE, Cole BE (2002) Annual primary production: patterns and mechanisms of change in a nutrient-rich tidal ecosystem. Limnol Oceanogr 47:698-712

Jauffrais T, Jesus B, Meleder V, Turpin V, Russo AAPG, Raimbault P, Martin-Jezequel V (2016) Physiological and photophysiological responses of the benthic diatom Entomoneis paludosa (Bacillariophyceae) to dissolved inorganic and organic nitrogen in culture. Mar Biol 163: 115

Kallqvist T, Svenson A (2003) Assessment of ammonia toxicity in test with the microalga, Nephroselmis pyriformis. Chlorophyta. Water Res 37:477-484

Khoo KH, Culberson CH, Bates RG (1977) Thermodynamics of the dissociation of ammonia ion in seawater from 5 to $40^{\circ} \mathrm{C}$. J Solution Chem 6:281-290

Kimmerer WJ (2002) Effects of freshwater flow on abundance of estuarine organisms: physical effects or trophic linkages. Mar Ecol Prog Ser 243:39-55

Kimmerer WJ, Ignoffo TR, Kayfetz KR, Slaughter AM (2017) Effects of freshwater flow and phytoplankton biomass on growth, reproduction, and spatial subsidies of the estuarine copepod Pseudodiaptomus forbesi. Hydrobiologia 807:113-130

Kraus TEC, Carpenter KD, Bergmaschi BA, Parker AE and others (2017) A river-scale Lagrangian experiment examining controls on phytoplankton dynamics in the presence and absence of treated wastewater effluent high in ammonium. Limnol Oceanogr 62:1234-1253

Krom M (1991) Importance of benthic productivity in controlling the flux of dissolved inorganic nitrogen through the sediment-water interface in a hypertrophic marine ecosystem. Mar Ecol Prog Ser 78:163-172

Kromkamp J, Peene J, van Rijswijk P, Sandee A, Goosen N (1995) Nutrients, light and primary production by phytoplankton and microphytobenthos in the eutrophic, turbid Westerschelde estuary (The Netherlands). Hydrobiologia 311:9-19

Kudela RM (2010) Does horizontal mixing explain phyto- 
plankton dynamics? Proc Natl Acad Sci USA 107: 18235-18236

Lakeman MB, von Dassow P, Cattolico RA (2009) The strain concept in phytoplankton ecology. Harmful Algae 8: 746-758

Lehman PW (1996) Changes in chlorophyll a concentration and phytoplankton community composition with wateryear type in the upper San Francisco Bay Estuary. In: Hollibaugh JT (ed) San Francisco Bay: the ecosystem. Am Assoc Adv Sci, Pacific Division, San Francisco, CA, p 351-374

Lehman PW (2000) Phytoplankton biomass, cell diameter, and species composition in the low salinity zone of Northern San Francisco Bay Estuary. Estuaries 23: 216-230

Levasseur M, Thompson PA, Harrison PJ (1993) Physiological acclimation of marine phytoplankton to different nitrogen sources. J Phycol 29:587-595

MacIntyre HL, Geider RJ, Miller DC (1996) Microphytobenthos: the ecological role of the 'secret garden' of unvegetated, shallow-water marine habitats. I. Distribution, abundance and primary production. Estuaries 19: 186-201

Margalef R (1978) Life-forms of phytoplankton as survival alternatives in an unstable environment. Oceanol Acta 1: 493-509

McIntire CD (1978) The distribution of estuarine diatoms along environmental gradients: a canonical correlation. Estuar Coast Mar Sci 6:447-457

* Moskalski S, Torres R (2012) Influences of tides, weather, and discharge on suspended sediment concentration. Cont Shelf Res 37:36-45

Müller-Solger A, Jassby AD, Muller-Navarra D (2002) Nutritional quality of food resources for zooplankton (Daphnia) in a tidal freshwater system (Sacramento-San Joaquin River Delta). Limnol Oceanogr 47:1468-1476

Nixon PJ, Michoux F, Yu J, Boehm M, Komenda J (2010) Recent advances in understanding the assembly and repair of photosystem II. Ann Bot (Lond) 106:1-16

Orlando JL, McWayne M, Sanders C, Hladik M (2014) Dissolved pesticide concentrations entering the Sacramento-San Joaquin Delta from the Sacramento and San Joaquin Rivers, California, 2012-2013. U.S. Geological Survey Data Series 876

Paasche E (1971) Effect of ammonia and nitrate on growth, photosynthesis, and ribulosediphosphate carboxylase content of Dunaliella tertiolecta. Physiol Plant 25:294-299

Parker AE, Dugdale RC, Wilkerson FP (2012) Elevated ammonium concentrations from wastewater discharge depress primary productivity in the Sacramento River and the northern San Francisco Estuary. Mar Pollut Bull 64:574-586

R Core Team (2016) R: a language and environment for statistical computing. R Foundation for Statistical Computing, Vienna

Raven JA, Wollenweber B, Handley LL (1992) A comparison of ammonium and nitrate as nitrogen sources for photolithotrophs. New Phytol 121:19-32

Ribeiro L, Brotas V, Mascarell G, Coute A (2003) Taxonomic survey of the microphytobenthic communities of two

Editorial responsibility: Max Tilzer,

Konstanz, Germany
Tagus estuary mudflats. Acta Oecol 24:S117-S123

* Richardson K, Bendtsen J, Kragh T, Mousing EA (2016) Constraining the distribution of photosynthetic parameters in the global ocean. Front Mar Sci 3:269

Ruhl CA, Schoellhamer DH (2004) Spatial and temporal variability of suspended-sediment concentrations in a shallow estuarine environment. San Francisco Estuar Watershed Sci 2:2-10

* Schoellhamer DH, Wright SA, Drexler JZ (2012) A conceptual model of sedimentation in the Sacramento-San Joaquin River Delta. San Francisco Estuar Watershed Sci 10:1-25

Sommer T, Armor C, Baxter R, Breuer R, and others (2007) The collapse of pelagic fishes in the upper San Francisco Estuary. Fisheries (Bethesda, Md) 32:270-277

Strom SL, Bright KJ (2009) Inter-strain differences in nitrogen use by the coccolithophore Emiliania huxleyi and consequences for predation by a planktonic ciliate. Harmful Algae 8:811-816

*Thessen AE, Bower HA, Stoecker DK (2009) Intra- and interspecific differences in Pseudo-nitzschia growth and toxicity while utilizing different nitrogen sources. Harmful Algae 8:792-810

Thompson PA, Levasseur ME, Harrison PJ (1989) Lightlimited growth on ammonium vs. nitrate: What is the advantage for marine phytoplankton? Limnol Oceanogr 34:1014-1024

Tong S, Hutchins DA, Fu F, Gao K (2016) Effects of varying growth irradiance and nitrogen sources on calcification and physiological performance of the coccolithophore Gephyrocapsa oceanica grown under nitrogen limitation. Limnol Oceanogr 61:2234-2242

* Turpin DH (1991) Effects of inorganic N availability on algal photosynthesis and carbon metabolism. J Phycol 27: $14-20$

Underwood GJC, Kromkamp J (1999) Primary production by phytoplankton and microphytobenthos in estuaries. Adv Ecol Res 29:93-153

* Underwood GJC, Provot L (2000) Determining the environmental preferences of four estuarine epipelic diatoms taxa: growth across a range of salinity, nitrate and ammonium conditions. Eur J Phycol 35:173-182

*Underwood GJC, Phillips J, Saunders K (1998) Distribution of estuarine benthic diatom species along salinity and nutrient gradients. Eur J Phycol 33:173-183

* Vass I, Styring S, Hundal T, Koivumiemi A, Aro E, Andersson B (1992) Reversible and irreversible intermediates during photoinhibition of the photosystem II: Stable reduced QA species promote chlorophyll triplet formation. Proc Natl Acad Sci USA 89:1408-1412

*Welschmeyer NA (1994) Fluorometric analysis of chlorophyll $a$ in the presence of chlorophyll $b$ and phaeopigments. Limnol Oceanogr 39:1985-1992

Wood G, Flynn KJ (1995) Growth of Heterosigma carterae (Raphidophyceae) on nitrate and ammonium at three photon flux densities: evidence for N-stress in nitrategrowing cells. J Phycol 31:859-867

*Wu H, Roy S, Alami M, Green BR, Campbell DA (2012) Photosystem II photoinactivation, repair, and protection in marine centric diatoms. Plant Physiol 160:464-476

Submitted: October 12, 2018; Accepted: February 21, 2019

Proofs received from author(s): April 8, 2019 